\title{
Ovarian Cancer and Primary Peritoneal Carcinoma pT1a TNM Finding v7
}

National Cancer Institute

\section{Source}

National Cancer Institute. Ovarian Cancer and Primary Peritoneal Carcinoma pT 1a TNM

Finding v7. NCI Thesaurus. Code C89643.

Ovarian cancer limited to one ovary; capsule intact, no tumor on ovarian surface. No

malignant cells in ascites or peritoneal washings. (from AJCC 7th Ed.) 